\title{
Experience Changes Perceptions: Arabic-Speaking Students' Perceptions Regarding the PDS Model and Teacher Training
}

\author{
Orr Levental $^{1}$, Edni Naifeld ${ }^{1}$, Saleh Kharanbe ${ }^{1} \&$ Marcel Amasha ${ }^{1}$ \\ ${ }^{1}$ Ohalo Acdemic College, Israel \\ Correspondence: Edni Naifeld, Ohalo Acdemic College, Israel.
}

Received: October 10, 2019

Accepted: November 15, 2019

Online Published: January 29, 2020

doi:10.5539/ies.v13n2p115

URL: https://doi.org/10.5539/ies.v13n2p115

\begin{abstract}
During their studies, education students are required to engage practice-based experience in a collaborative model: Professional Development School (PDS), where there are many options for building professional and personal development processes. Through this experience, students formulate professional identity and perceptions about teaching. This study sought to examine the impact of this experience model on Arabic-speaking education students attending a Hebrew speaking college. The effect of the practice-based experience was examined on both the concept of teaching as a profession, the process of teaching instruction and social and cultural aspects. The findings of the study showed that PDS practice-based experience directly and indirectly contributes to the way students perceive teaching, the role of the teacher, the education system, as well as the importance of the practical experience in the teaching training process. However, there was no significant contribution of PDS practice-based experience to students' perceptions of multicultural aspects of campus life.
\end{abstract}

Keywords: teacher training, Israeli-Arab, PDS, multiculture, higher education

\section{Introduction}

\subsection{Arabic-Speaking Students' Perceptions Regarding the PDS Model and Teacher Training}

As of 2019, teacher training in Israel is a four-year study program leading to a BED degree, taught at educational institutions designated for training teachers. To complete this degree, education students are required to engage in practice-based experience in the schools. One model for acquiring this experience is the Professional Development School (PDS) model, which entails ongoing cooperation between the students, the colleges of education and the schools. The research literature indicates that this model exerts a positive influence on students' entry into the teaching profession (see, for example, Walling \& Lewis, 2000). Yet, the implications of this model in shaping students' perceptions of the nature and quality of the training process have received only marginal research attention. These implications are particularly important in the Israeli context. Israeli institutions of higher education serve as an arena for intercultural encounters that provide students - both Jews and Arabs - with their first opportunity for meaningful, direct and long-term contact. Indeed, these encounters are instrumental in shaping students' perceptions of the other in society, in the teaching profession and in their learning experience at college. The basic assumption of this research is that the PDS model as implemented among Arab students helps them connect to the teaching profession and provides them with a more holistic perspective on the education system. Hence, the model also has the potential to exert a positive influence on other aspects related to their training. Indeed, the assumption is that experience with the PDS model will on the one hand generate a stronger connection to the teaching profession and hence improved social relations with other education students, while on the other hand it will produce more positive perceptions of the course of study. The current research examines the perceptions of Arabic-speaking students (Muslims, Christians, Druze and others) with respect to two topics: 1) the teacher training process itself and 2) the teaching profession as a whole. The research focuses particular attention on intercultural encounters during the students' theoretical studies and practical experience. To this end, the research adopted a qualitative approach that entailed 60 in-depth interviews with Arabic-speaking education students at a college in northern Israel who acquired their practical experience through the

\subsection{Perceptions of Teacher's Role}

The objective of teaching is to shape children's education and influence their future by teaching values, developing intellectual abilities, imparting knowledge and skills, mediating interpersonal relations and more. In theory, these 
elements should contribute to the social and economic prestige of the teaching profession. Nevertheless, opinions of the teaching profession vary across the globe. In some countries teaching is considered a valued and desirable profession, while in others it is labeled as inferior and profession (Hargreavers, 2009). In Israel, opinions regarding the teaching profession also vary widely. On the one hand, teachers are valued and respected for choosing a respected profession that can lead to change. On the other hand, teaching is seen as an unattractive profession lacking in prestige. In addition, the negative perceptions of teaching as a profession clash with its perceived status as superior to other professions (Gilat \& Wengrowicz, 2018). Moreover, despite reforms seeking to improve the status and working conditions of Israeli teachers, the public and the teachers themselves still consider the status of teaching to be mediocre (fifth out of six academic professions) (Gilat \& Wengrowicz, 2018).

Hoyle (2001) defined professional status as a concept linked to social status. With respect to the teaching profession as well, the quality of the job is related to society's perceptions of its status. Hence, improving the social status of teachers is of major importance. Hoyle identified three levels of teachers' status: professional prestige - how teachers are perceived in the public hierarchy of professions; occupational status - how teachers are evaluated relative to the ranking of other educated groups; and professional assessment - how the public assesses the profession based on the special abilities it requires. These perceptions emerge from social approaches and therefore are liable to change with the times. Thus, for example, in the first decades of Israeli statehood, teachers were considered essential and meaningful for students and the entire community because they were leaders who brought about change. As the years went by, however, the status of teachers in society began to erode (Ben-Peretz, 2009; Gilat \& Wengrowicz, 2018). Among the reasons for the negative view of the teaching profession are the low impression of teachers' academic and professional level and the unattractive salary and working conditions. In addition, the rise in behavioral problems, discipline issues and violence among students and the difficulties in interacting with parents are also factors in the reluctance to enter this field (Hargreavers, 2009).

Yet despite the above, every year thousands of new students enroll in the colleges of education, aspiring to become teachers. Seeking to understand students' motives for choosing the teaching profession, Fray and Gore (2018) surveyed 70 research studies conducted between 2007 and 2016. They distinguished between internal objectives (e.g., personal passion for teaching, inner motivation, desire to influence, help and contribute to society) and external objectives related to juggling family and work and to working and employment conditions. The researchers also found that in non-Western countries marked by greater economic distress, external factors had more influence, while in other countries internal motivations were more dominant. A study conducted in Israel compared prospective college students not interested in becoming teachers with those focused on becoming teachers in an attempt to understand what singles out those who choose the teaching profession (Arnon, Frankel, \& Rubin, 2015). The research findings indicate that the primary considerations among potential education students were the nature of the profession and the satisfaction to be gained from it, while external considerations such as salary and conditions were of secondary importance. The researchers found that the considerations in choosing the teaching profession sharpened its social context as well as its potential for contribution, change, influence, learning and personal development. In addition, the prospective students interested in becoming teachers tended to overlook the difficulties posed by status and salary (Arnon, Frankel, \& Rubin, 2015). A similar study was conducted in the Arab sector, where the demand to study the teaching profession is higher despite the limited future employment opportunities (Aliyan, Zidan, \& Toren, 2007). The findings indicate that in this population group the family, in particular for the father, exerts a major influence in the choice of the teaching profession. In addition, the intellectual motive of challenge and love for the profession was also significant, while the economic motive was found to be less significant. Furthermore, the study found that gender and economic status were related to choosing the teaching profession, such that the many women who chose to study education saw teaching as an honorable and prestigious profession in their society. The social structure did not require these women to support the family and therefore they did not attribute much significance to the economic factor (Aliyan, Zidan, \& Toren, 2007).

\subsection{PDS}

Teacher education institutions aim to find the best way to provide prospective teachers with high academic and practical abilities that will enable them to integrate successfully in the education system. Accordingly, the course of studies at the education colleges is geared toward experience-based learning. This notion hinges on the understanding that active learning through actual and varied experiences in the presence of a qualified teacher trainer constitutes the best way to prepare education students for their work (Whitford \& Barnett, 2016).

In Israel today there are three major models of practical teaching experience: The first model is the traditional model, in which students are assigned to schools for one day (6 hours) of practice teaching per week. A pedagogical instructor from the college carries out a limited number of classroom observations and feedback during the year. No emphasis is placed on the relationship between the school and the college, and choosing the 
experience is up to the teacher trainer. The students engage in a marginal amount of practice, with most of the learning based on imitating the model offered by the classroom teacher and less on actual hands-on teaching experience (Lahavi, 2010; Aliyan \& Daniel-Saad, 2013). The second model is the Professional Development School model (PDS), which includes extended practical experience in selected schools along with collaboration between the college and the school (Ariav, 2014; Ariav \& Semet, 2006; Maskit \& Mevarech, 2013). The third model is the Academia-Classroom model. It entails intensive practical experience in the school three days a week in a co-teaching setting together with the teacher-trainer, based on the principles of PDS (Ministry of Education, 2014).

Despite the practical experience that is an essential part of teacher training in all these models, beginning teachers still experience initial professional shock or first-year reality shock. These teachers report feelings of confusion, isolation, frustration, lack of confidence and inadequacy and describe "survival efforts," "shock" and "chaos" (Farrell, 2016). Nevertheless, committees of experts charged with examining the state of teacher education in Israel have proposed various courses of study, among them increasing the number of academic hours at the expense of practical field experience (Aliyan \& Daniel-Saad, 2013, Ariav Commission Report, 2007). Maskit and Mevarech (2013) describe some of the difficulties such changes cause among new teachers, including insufficient hours of practical experience and weakened ties between the schools and the colleges. According to them, the focus of teacher training should be shifted from academic studies to training based on clinical experience in the teaching field, as manifested in the PDS model.

According to Kolb (1983), learning is based primarily on the transformation of experience. That is, the more closely tied learning assignments are to learners' work, the greater their motivation to learn, thus enabling learners to focus on and understand the relations between practice and theory (Dressler, 2013). Like clinical experience in other professions such as medicine, clinical experience in teaching provides learners the opportunity to become familiar with all aspects of the school, to try out a variety of teaching options and to develop ties with all the partners - students, teacher trainers, the school staff and the college academic staff (Ariav, 2014; Maskit \& Mevarech, 2013).

Boerboom et al. (2011) outline the following necessary conditions for clinical experience:

- Demonstration: Demonstrating a variety of teaching situations and providing students the opportunity to participate in these situations.

- $\quad$ Practice: Providing students with many opportunities to practice teaching themselves and providing feedback on each such practice session.

- Explanation: Clarifying considerations involved in choosing teaching methods and explaining theoretical bases.

- Self-examination and self-discovery: Creating opportunities to enable students to examine themselves and evaluate the quality of their work.

- Positive climate: Creating a supportive atmosphere that is respectful of the students and reinforces their sense of self-efficacy and motivation.

The PDS model provides these conditions through clinical experience in the teaching field. The model creates a sense of partnership between the teacher education institutions and the schools and preschools where the practice takes place (Ariav \& Semet, 2006). This partnership entails improving the processes included in training education students and adapting them to the school reality, as well as exposing students to a variety of teaching options and familiarizing them with school life, all based on long-term and meaningful contact (Maskit \& Mevarech, 2013; Levin, 2002). At the same time, additional goals are accomplished, among them professional development of the teacher-trainers and improvement in the achievements of the school students (Abdal-Haqq, 1998).

\subsection{Intercultural Encounters in Higher Education}

Higher education institutions in Israel often provide Arab students their first opportunity to participate fully in Israeli society, mainly because these institutions offer them their first chance to meet people from other religious and cultural groups (Diab, 2002). The Israeli school system is divided into state schools, state religious schools and Arab schools. To a certain extent this division also exists in higher education, at least in teacher training, with several colleges targeting Arabic-speaking students exclusively: the Arab College for Education in Haifa, Al-Qasemi College and the College of Sakhnin for Teacher Education. According to Davidovitch et al. (2007a), there are no clear criteria according to which education students choose where to study. This is despite the obvious limitations facing Arab students seeking to enroll in Jewish colleges of education where the language of instruction is Hebrew, which is not their mother tongue. For the most part, Arab students choose Jewish colleges based on 
their perception of higher education studies as a tool for social connection and achieving equality between Jews and Arabs (Davidovitch et al., 2007b). Similarly, Suan et al. (2007) found that the intercultural encounter at Jewish colleges enhances the Israeli identity of the Arab students, which according to Mi'ari and Diab (2005) is not dominant prior to this encounter. These authors also claim that Arab students in higher education are much more motivated than their Jewish counterparts to develop friendly relations with students from other ethnic groups. The authors stress that this low willingness from the outset creates a situation in which there are practically no social interactions between students from different ethnic groups except in academic/study contexts. Despite these biased conclusions on the part of Mi'ari and Diab (2005), their objective findings point to a correlation between definitions of self-identity among Arab students (who they refer to as Palestinians) and their willingness to interact socially with Jews. These findings indicate that a change in self-perceived identity can exert a positive or negative influence on perceptions of multiculturalism during higher education studies. While researchers artificially focus on the clear contrasts between Muslims and Jews and between Palestinians and Israelis, in practice their changing professional or academic perspectives should also be examined, as proposed in the current study.

The first encounter between students from different cultural backgrounds naturally contributes to changing their perceptions. Nevertheless, other factors likely to affect students' perceptions must also be considered, among them the training process, professional perspectives, the specific curriculum and others. The training is geared toward the students' future jobs as teachers and toward instilling social and democratic values. Therefore, during the course of their studies the students participate in courses and workshops designed to teach them about the diverse voices and groups comprising the population of Israel (Lev-Ari \& Laron, 2008). Teacher training programs that include courses and workshops focusing on multiculturalism reinforce students' views that multiculturalism should be recognized as an integral part of the teaching profession; both as an educational value and as a tool for coping with the reality in the schools (see also Perry, 2007). Nonetheless, the study by Lev-Ari and Laron (2008) also revealed voices calling for separating teacher education institutions along ethnic lines. This demand represents a particularistic approach adopted by students after intercultural encounters on campus. According to these authors, the limited impact of multicultural education stems from the lack of practical tools and the focus on theoretical considerations. They advocate the alternative provided by practical experience, which has a greater influence in training students and in changing their perspectives. Diab et al. (2008) also examined intercultural encounters at teacher education colleges. They found that group study, preferably involving heterogenous groups and crossing academic tracks, has an advantage in influencing students' views. Moreover, breaking down the hierarchical authority of the instructors is important so as to obtain their equal participation and to enhance the learners' responsibility. The findings of Perry (2007) also point to the importance of team learning in teacher education and promoting multiculturalism. Perry contends that teacher education helps in developing dialogue and self-awareness among students, thus also reducing the level of stress surrounding ideological issues. According to Abu Jaber and Amer (2012), an important difference in the teacher training process can be found in the market demand for teachers according to sectors. While the demand for Jewish teachers is high, the Arab sector is saturated with preservice teachers. Because most teachers teach in their own sectoral education system, professional perspectives may differ from one student to another. Indeed, Arab students' perspectives on multiculturalism and on Jews are influenced by the very fact that they are studying in a Jewish institution, as reflected in their practical experience and group learning, specific courses on culture and society and changing views of the teaching profession. All of this is provided through a challenging program, and particularly in the extended PDS experience inherent in this program. Hence, one can assume that beyond its direct objectives, this experience will have an impact on the multicultural perspectives of Arab students.

\section{Method}

This study examined students' perspectives on their training and on the teaching profession, and particularly their perspectives regarding multiculturalism. The overriding objective of the research was to examine the degree to which the PDS program influences students' perspectives on the teaching profession, the training process and the notion of multiculturalism. To achieve this objective, the research adopted the qualitative approach, using semi-structured in-depth interviews as the research tool. The research population comprised 60 Arabic-speaking students who participated in the PDS model at a college in northern Israel. The interviews took place at the beginning and the end of the 2017-2018 academic year and were conducted by the researchers and by research assistants recruited for this purpose. The researchers do not teach in the PDS program nor are they involved in it in any way. The interviews focused on the students' perceptions with respect to three topics: their training, the teaching profession and multiculturalism. The interviews were conducted freely and without any predefined terms in order to extend the students' individual context regarding the researched topics. The interviews were recorded. The two interviewers analysed the data separately and then discussed their analyses to determine similarities and 
differences.

\section{Discussion}

Two main themes emerged from the interviews, one regarding perspectives on the teaching profession and the other regarding the impact of practical experience on other aspects of the training. Each theme included two separate dimensions. With respect to perspectives on the teaching profession, the students pointed to professional prestige and the teacher's goals on the one hand and to the nature of the teacher's activities and the multiculturalism required by the job on the other. With respect to the implications of practical experience, the students referred to the role of experience in the overall context of their training as well as to their relations within the social-cultural component on campus. In the following sections we discuss these two themes as they emerged from the interviews.

\subsection{Perspectives on the Teaching Profession}

The picture that emerged from analysis of the interviews conducted with students who gained their practical teaching experience according to the PDS model pointed to their evolving perception of teaching as a superior and valuable profession with positive components both for the students and for society. The participants' responses were extremely emotional, revealing their enthusiasm and suitability for the job, yet perhaps also their immaturity and inability to interpret reality. From the outset, those pursuing a career in education believe they are suited for the job and that the job is worthy. As seen in the study by Arnon, Frankel and Rubin (2015), those interested in a career in education were ethically motivated for this field and tended to disregard the inherent difficulties of the profession. In addition, these education students had already gained a year of practical experience according to the PDS model, which included guidance from a teacher trainer and support from a pedagogical instructor from the college. Through this experience, they received maximum exposure to the teaching profession, engaged in practical teaching experience and experienced school life (Ariav, 2014; Ariav \& Semet, 2006; Maskit \& Mevarech, 2013). One interviewee, for example, stated the following: "I believe that practical training and experience is one thousand times better than theoretical training. The experience gave me the motivation to continue on my chosen path, to learn from my mistakes and to improve my skills." The interviews also indicated that the chosen school provided the students with a different model of teaching, thus improving the image of teaching in their eyes and reinforcing their positive perceptions of the profession. Even so, a utopian and immature picture of the profession may develop among these young students, which in the future is liable to lead to problems when they actually enter the classroom. These difficulties in coping with teaching often find expression in first-year reality shock (Simon, 2005). Nevertheless, the students examined in this study are scheduled to undergo an additional year of practical experience as part of another Ministry of Education project known as Academia-Classroom, where they will be exposed to additional aspects of working in the schools (Ministry of Education, 2014).

Alongside their utopian perception of the profession, the students in the program recognized that teaching is not sufficiently valued in Israeli society, as reflected in the public discourse (Gilat \& Wengrowicz, 2018). Even though the participants were from the Arabic-speaking sector where teaching is more valued by society (Aliyan, Zidan, \& Toren, 2007), they attend a mixed college and are to some extent aware of the general public discourse. The participating students defined teaching as a multi-directional profession. In contrast to traditional practical experience, the students did not concentrate only on observation and practice in one particular content area or discipline (Lahavi, 2010). Rather, they accompanied one mentor teacher and were exposed to school life and the various layers of the teacher's job. The above analysis indicates that experience based on the PDS model succeeded in exposing the students to diverse aspects of the teacher's job and in providing a holistic view of teaching with respect to content as well as to the emotional, social, ethical and cultural aspects of the job (Maskit \& Mevarech, 2013).

\subsection{Cultural and Systemic Aspects}

The PDS model is marked by cooperation and partnership. The model is based on the rationale that the transition from preservice teachers' narrow and individualistic perceptions to their perceptions of an educational community takes place at the school. Hence, the presence of a large number of students gaining their practical experience at the same school promotes the social and communal aspect of their training and contributes to a sense of group responsibility. These aspects came up frequently in the interviews. The students mentioned the collective contribution of the experience as well as what it contributed to them personally. Accordingly, the current study examined whether attitude toward the other has a direct or indirect impact on other social aspects of the theoretical training. That is, does the social perspective gained during the practical experience also find expression in learning processes that take place in the classroom and elsewhere on campus, and particularly multicultural elements.

At this point it is important to note one major limitation that emerged from the interviews: the religious 
segregation in the formal education system in Israel. Indeed, in Israel there are four separate school systems: Orthodox Jewish religious schools based on the Torah, state religious schools for the traditional-religious Jewish population, state schools for the secular Jewish population and Arab schools attended by diverse Arabic-speaking population groups. Moreover, various groups are distinguished even within this division. For example, different streams within Orthodox Judaism are separated. In the case of the Arab sector, which is the focus of this study, the different religious groups (e.g., Christians, Druse, Muslims, Circassians) are separated, though this separation is to a large extent dependent upon the geographical dispersion of the population. For this reason, for most of the students their group interactions in the practical experience setting did not expose them to other cultures but rather only to other individuals within their social system. Hence, for most of the Arabic-speaking students, the multicultural encounter in the classrooms and on campus constituted a different environment from their practical experience. Furthermore, in the chosen case the Arabic-speaking students at the college study in Hebrew and must pass Hebrew-language exams to be admitted to the college. That is, these students are apparently more open to the Jewish population and more proficient in Hebrew, thus enabling them to connect more easily to the Jewish population on campus.

The findings of the current study regarding multicultural perceptions of the training process point to ambivalence among the interviewees. The difference in their approach to the overall context of multicultural social relations is apparent. Most of the interviewees pointed to a major discrepancy between these relations in the classroom and during learning process and those expressed in the breaks between classes and the social activities held throughout the year. One interviewee, for example, stated the following: "There are many sectors at the college. We are all friends. In class I get help in understanding texts, but in the breaks we usually split up into groups according to sector." The interviewees also stated that when collaboration is built into classroom activities and assignments, as in the practical experience at the schools, the connection is positive. Even when they clearly understand that this connection is intentional and artificial, the students still feel it is valuable and are happy to take part. Another point that emerged is that this connection has a direct impact on their individual training, due to the help they receive in their studies and mainly to the knowledge they gain by working together. These aspects also emerged in their attitudes toward the practical experience and point to the students' willingness to take part in shared learning processes. This approach is in line with the findings of Diab et al. (2008) regarding the role of multicultural encounters in higher education.

Despite this positive attitude toward the classroom environment, the interviews revealed a different picture regarding multicultural relations on campus and in extracurricular activities. In this context the students see the relations as random, superficial and external to their overall learning experience. One interviewee, for example, stated the following: "To me the social life on campus seems quite deficient. There's no attempt at cooperation or joint activities between the different sectors." Despite the positive evidence of educational cooperation in the practical experience and in the classroom, the interviewees do not show dissatisfaction with the lack of communal social relations. This point is interesting for it indicates that the students have a positive view of the activities geared to bringing the sectors together and do not necessarily see the lack of shared social relations as negative. This finding is in line with the findings of Suan et al. (2007) regarding the change in perception emerging from multicultural encounters. The implication for the PDS model is that students are aware of its potential advantages and that their positive perceptions are the result. In contrast, students who gain their practical experience according to more traditional models are liable to perceive their present situation as advantageous. Another important aspect is that when the interviewees express their opinion on multiculturalism they do not think exclusively in terms of the Jewish-Arab divide but rather also consider the segregation between different religious groups among the Arabic speakers. As indicated, this can be attributed to the segregation in the schools where they gain their practical experience, which stems from governmental, geographic and social practices in Israel.

\subsection{Conclusion and Recommendations}

In the context of the extensive academic literature on the direct advantages of the PDS model for practical teaching experience, the current study sought to examine the advantages of this model in shaping aspects accompanying the teacher training process: perceptions of the profession and the job of the teacher and perceptions of multiculturalism at the colleges. The rationale for examining these indirect influences is that attributes of practical teaching experience contribute to developing thought processes and reshaping the individual's role in the system and hence are likely to influence these aspects of teachers. The research findings indicate that practical experience does indeed have direct and indirect effects on how students perceive the role, identity and educational objectives of the teacher. Moreover, the interviewees indicated that they gained a better understanding of the entire education system and of the decisive importance of practical experience in teacher training. In contrast, the model was not found to make any major contribution to the students' perceptions regarding social and multicultural aspects of 
campus life. The students did distinguish between the educational setting and all the other student activities, pointing to the need for active intervention in the educational context to maximize the advantages of joint activities. The research findings also show that the students consider cooperative learning in any training setting as positive, not only with respect to the effectiveness of cooperation between individuals but also regarding a change in perceptions of the importance of the group to individual development. Because perceptions of the teacher's role on the one hand stem from training while on the other hand influence the social prestige of the teaching profession and the tendency of students to choose this field, it is important to implement cooperative aspects both in the practical experience model and in the theoretical studies.

This study focused on a particular case of one college in northern Israel. Despite the large number of participants, their geographic distribution is relatively limited, perhaps indicating a certain bias in the responses deriving from the cultural and social attributes of the population in the region. In addition, there were relatively few Circassian, Bedouin and Christian interviewees. Future research should extend the research population to include these groups. Another variable that constituted a limitation is the relatively large number of students majoring in physical education, whose motivations for studying - which include the prestige of this field and the lack of alternative programs of study in Israel focusing on sports - may differ from those of education students majoring in other disciplines. Future research to examine the statistical connections within the findings of this study would be an important addition to this initial research. We also recommend studying similar cases in different regions in Israel to shed light on the unique features of the Arabic-speaking groups in Israel.

\section{References}

Abdal-Haqq, I. (1998). Professional development schools: Weighing the evidence. Thousand Oaks, CA: Corwin Press.

Abu Jaber, S., \& Amer, A. (2012). Professional Development Schools (PDSS) as a Teacher Training Reform in Two Arab Teacher Training Colleges in Israel. Jämiah, 95(381), 1-27.

Aliyan, S., \& Daniel-Saad, A. (2013). Shift from the traditional model of practical experience to the cooperative model—Slogan or necessity? Dapim, 56, 35-39 (Hebrew).

Aliyan, S., Zidan, R., \& Toren, Z. (2007). Motives for choosing the teaching profession among preservice teachers in the Arab sector. Dapim, 44, 123-147 (Hebrew).

Ariav Commission Report. (2007). Guidelines for teacher training at institutions of higher education in Israel. Jerusalem: Council for Higher Education (Hebrew).

Ariav, T. (2014). Practical experience in teacher training: "Recalculating the route." Journal of the Mofet Institute, 53, 13-19 (Hebrew).

Ariav, T., \& Semet, K. (2006). Creating partnership between teacher education institutions and the field: An international look emphasizing the Professional Development School (PDS) model. In M. Silberstein, M. Ben-Peretz, \& N. Greenfeld (Eds.), New trend in teacher training programs: Partnership between colleges and schools-the Israeli Story (pp. 21-67). Tel Aviv: Mofet Institute (Hebrew).

Arnon, R., Frankel, P., \& Rubin, I. (2015). Dropout and rejection factors in choosing the teaching profession. Dapim, 59, 17-44 (Hebrew).

Ben-Peretz, M. (2009). Position paper on "The status of teachers: New directions". University of Haifa. Retrieved from https://ecat.education.gov.il/Attachment/DownloadFile?downloadId=7608

Boerboom, T. B. B., Dolmans, D. H. J. M., Jaarsma, A. D. C., Muijtjens, A. M. M., Van Beukelen, P., \& Scherpbier, A. J. J. A. (2011). Exploring the validity and reliability of a questionnaire for evaluating veterinary clinical teachers' supervisory skills during clinical rotations. Medical Teacher, 33, 84-91. https://doi.org/10.3109/0142159x.2011.536277

Davidovitch, N., Suan, D., \& Kollan, M. (2007a). Cultural setting and objective difficulties of Arab students at two public colleges. Judea and Samaria Studies, 16, 413-432 (Hebrew).

Davidovitch, N., Suan, D., Kollan, M. (2007b). Colleges as preparers for social equality. Kivunim Hadashim, 16, 213-234 (Hebrew).

Diab, K. (2002). The missing narrative: Self-searching. Bamichlala 13, 147-172 (Hebrew).

Diab, K., Bar Shalom, Y., \& Russo, A. (2008). Extending the encounter and learning between different cultural groups in Israeli society: A case study from teaching training at an academic college of education. Bamichlala-Research, Study and Creation, 211-252 (Hebrew). 
Dressler, M. (2013). Kolb's circle of learning. Eureka, 36, CET Publications (Hebrew).

Farrell, T. S. (2016). From trainee to teacher. Reflective practice for novice teachers. London: Equinox.

Fray, L., \& Gore, J. (2018). Why people choose teaching? A scoping review of empirical studies 2007-2016. Teaching and Teacher Education, 75, 153-163. https://doi.org/10.1016/j.tate.2018.06.009

Gilat, Y., \& Wengrowicz, N. (2018). The status of teachers in Israeli society today. Dapim, 68, 11-27 (Hebrew).

Hargreaves, L. (2009). The status and prestige of teachers and teaching. In International handbook of research on teachers and teaching (pp. 217-229). Springer, Boston, MA. https://doi.org/10.1007/978-0-387-73317-3_13

Hoyle, E. (2001). Teaching: Prestige, status and esteem. Educational Management \& Administration, 29(2), 139-152. https://doi.org/10.1177/0263211X010292001

Kolb, D. A. (1983). Experiential Learning: Experience as the Source of Learning and Development. Prentice-Hall, Englewood cliffs, New-Jersey.

Lahavi, Y. (2010). Hands first and foremost: On practical experience in teacher training. Masa, Mofet Institute. Retrieved from http://portal.macam.ac.il/ArticlePage.aspx?id=2882

Lev-Ari, L., \& Laron, D. (2008). Education for multiculturalism at a college of education: From theory to practice. Social Issues in Israel, 5, 131-134 (Hebrew).

Levine, M. (2002). Why invest in professional development schools? Educational Leadership, 59, 65-68.

Maskit, D., \& Mevarech, Z. (2013). Another way is possible: Educating teachers according to the partnership model of PDS. Dapim, 56, 15-34 (Hebrew).

Mi'ari, M., \& Diab, K. (2005). Social identity and willingness for social relations with Jews among Arab students at a teacher education college. From a collection of articles by lecturers at David Yellin College of Education (pp. 533-563, Hebrew).

Ministry of Education. (2014). Academia-Classroom partnership to reinforce teaching: Think team summary policy statement. Retrieved from http://academia-kita.macam.ac.il/policy/

Perry, P. (2007). Developing social sensitivity among students of education. In P. Perry (Ed.), Education in a multicultural society: Pluralism and meeting points between cultural rifts. Jerusalem: Carmel (Hebrew).

Suan, D., Davidovitch, N., \& Kollan, M. (2007). A question of identity: On the identity of Arab and Jewish students on two college campuses in Israel. Hahinuch vesevivo, 19, 167-182 (Hebrew).

Walling, B., \& Lewis, M. (2000). Development of professional identity among professional development school preservice teachers: Longitudinal and comparative analysis. Action in Teacher Education, 22(2A), 65-72. https://doi.org/10.1080/01626620.2000.10463040

Whitford, E. V., \& Barnett, B. E. (2016). The Professional Development School Approach to Teacher Education: Identification of a Model. In Conference Proceedings. The Future of Education (pp. 457-460). libreriauniversitaria. it Edizioni.

\section{Copyrights}

Copyright for this article is retained by the author(s), with first publication rights granted to the journal.

This is an open-access article distributed under the terms and conditions of the Creative Commons Attribution license (http://creativecommons.org/licenses/by/4.0/). 